\title{
THE AXIOLOGICAL DIMENSION IN PSYCHIATRIC DIAGNOSIS
}

\author{
Fernando Lolas Stepke*
}

\begin{abstract}
This paper addresses the need to consider the valoric constitution of patients and therapists in the context of psychiatric encounters and proposes the notion of axiogram, a depiction of values and moral beliefs to incorporate into the clinical history as a proxy to a nosological dimension complementing the traditional multiaxial approach.
\end{abstract}

Key words: psychiatric diagnosis, medical ethics, axiography, axiology

\section{LA DIMENSIÓN AXIOLÓGICA EN EL DIAGNÓSTICO PSIQUIÁTRICO}

Resumen: Este artículo se refiere a la necesidad de considerar la constitución valorativa de los pacientes y de los terapeutas en el contexto de los encuentros psiquiátricos, y propone la noción de axiograma, una descripción de valores y creencias morales que sea incorporada a la historia clínica como un apoyo a una dimensión nosológica que complemente la aproximación multiaxial tradicional.

Palabras clave: diagnóstico psiquiátrico, ética médica, axiografía, axiología

\section{A DIMENSÃO AXIOLÓGICA NO DIAGNÓSTICO PSIQUIÁTRICO}

Resumo: Este artigo se refere à necessidade de considerar a constituição valorativa dos pacientes e dos terapeutas no contexto dos encontros psiquiátricos e propõe a noção de axiograma, uma descrição de valores e crenças morais a ser incorporada à história clínica, como um apoio a uma dimensão nosológica que complementa a aproximação multiaxial tradicional.

Palavras-chave: diagnóstico psiquiátrico, ética médica, axiografia, axiologia

Interdisciplinary Centre for Bioethics, University of Chile, Santiago, Chile

Correspondence: flolas@uchile.cl 
As other value-based professions, psychiatry can be considered in a threefold perspective

a) As a social practice, characterized by spontaneous requesting and giving help and/or support to people in distress and affliction.

b) As a scientific discipline, grounded on the empirical biological and social sciences, responding to the scientific ethos of universalism, search for truth, and promotion of human welfare.

c) As a profession, an institutionalized response to societal needs and demands, characterized by commitment to the welfare of people, confidentiality and dignity.

In these three contexts, psychiatry involves human interaction and confronts the diversity and heterogeneity of the human condition(1). Freedom and autonomy are fundamental rights of persons and underscore the keystone of ethical reflection: the free election of ends and means for achieving personal plenitude.

Axiology, the philosophical discourse concerned with values and human behaviour as reflected in habit and custom, is an essential component of any psychiatric activity, be it diagnostic, prognostic or therapeutic. As unreflected social practice, scientific discipline, or profession, psychiatry needs considering the diversity of the human condition, the multiple ways in which personhood is manifested and preserved, and the cultural norm determining styles of interaction, of communicating illness, and of achieving wellbeing(2).

In diagnostic systems (and in the formulation of prognosis and therapy) the structure of values, beliefs and behavioural norms is not always explicitly considered and is frequently left to the common sense of practitioners without benefiting from progress made in bioethics, theory of values, and the metrics of moral algorithms developed in the humanities and the social sciences. The very complex nature of the notion of disorder or harmful dysfunction points to the importance of conceptual and practical interfaces in the diagnostic process which in turn influences prognosis and treatment(3).

Previous work has attempted to tackle the issues regarding moral evaluation in psychiatry without compromising the necessary pluralism that modern democratic societies require(3). Two main aspects may be emphasized here.
The first is the idea of including in the clinical evaluation the "axiogram" of both patients and clinicians. Axiogram is a term indicating depiction of the valoric constitution of a person, in much the same way as "ethogram" reflects behavioural patterns, hemogram shows blood composition, electroencephalogram depicts brain electrical activity and so on. Bringing moral and valoric structure to the same empirical level allows the incorporation of the valoric structure to the clinical history indicating that it constitutes essential part of it and merits consideration in evaluation and diagnosis. Prof. Hans-Martin Sass, of Bochum and Georgetown, devised the "Bochum Inventory", designed to assess the valoric constitution of patients. It consists of a series of questions and their appraisal in terms of valoric structures and terms reflecting what people think and feel about moral life with emphasis on medical worries and demands for attention and care(4).

Another approach consisted in defining the psychiatric "case" not as individual history, but as a "metatext" based upon three different narratives: one from the "patient", one from the "relevant others" and one from the therapist(5). These narratives -as texts- are combined into a single great narrative -a metanarrative- which can be analyzed by appropriate methods of content analysis oriented towards evaluating moral emotions. We have used the method proposed initially by Louis Gottschalk and further refined and adapted by us to other languages and to different clinical situations. The possibility of achieving an appropriate Axiography of the case is reinforced by considering, in one single analysis, the contributions from the subject, from his/her relevant others (relatives, friends, and acquaintances) and from the clinician reacting to the materials. We also envisioned adding the textual materials provided outside the clinical encounters and stemming from written productions of the subjects involved $(6,7)$.

The aim is make these sources of information on the moral world of persons useful to psychiatry in a valid, reliable and generalizable form. The axiographic dimension so defined could complement traditional axes so far used and contribute towards a true psychiatry of the person(s) as they constitute and are constituted in the encounter(8-10).

The notion of dimension instead of axis is appropriate to address the valoric (or axiological) component of diagnosis, for it pervades the whole practice of medicine 
and psychiatry, and not only the diagnostic process of getting a label. This is in keeping with a theory of medicine that considers that the true meaning of the medical encounter lies in the reconstruction of the person in need of help through many different languages (the technical, the everyday, and the moral). As this happens within a linguistic community, the essential aspect of psychiatry, and its valoric dimension lie on the assessment of words and meanings $(5,11)$. The need for an empirical Axiography is underscored by the vagueness of psychiatric entities and their association with cultural mores(12).

Recent publications stress the importance of psychiatry for the person and with the person(13). Further research on personal ethical constructs and its attendant axiography should be fostered in view of the dialogical nature of value-based professions such as psychiatry and medicine(14).

\section{References}

1. Lolas F. Mehrdimensionale Medizin. Medizinethische Materialien. Heft 21. Bochum: Zentrum für Medizinische Ethik Bochum; 1988.

2. Lolas F. Ethics in psychiatry: a framework. World Psychiatry 2006; 5 :185-187,

3. Wakefield JC. The concept of mental disorder: diagnostic implications of the harmful dysfunction analysis. World Psychiatry 2007; 6: 149-156.

4. Sass H.M. Bochumer Arbeitsbogen zur medizinethischen Praxis Medizinethische Materialien. Bochum: Zentrum für Medizinische Ethik; 1987 (English, Japanese, Spanish and Portuguese translations in 1988).

5. Lolas F. Psycholexicology: Psychiatric discourse and nosological entities. Psychopathology 1997; 30: 241-244.

6. Lolas F, Valdebenito C. La inter-textualidad en la construcción del caso psiquiátrico. Revista de Psiquiatría Clínica (Santiago) 2004a; 41: 27-31.

7. Lolas F, Valdebenito C. Hacia una reconstrucción técnico-axiográfica del caso en psiquiatría: una nota bioética. Revista de Neuro-Psiquiatría (Lima) 2004b; 67: 182-187.

8. Lolas F. The psychosomatic approach and the problem of diagnosis. Social Science and Medicine 1985; 21: 13551361.

9. Lolas F. Hacia una psiquiatría multidimensional. Investigación en Salud (Guadalajara, México) 1999; 1: 29-33.

10. Lolas F. Bioethics and psychiatry: a challenging future. World Psychiatry 2002; 1: 127-128.

11. Lolas F. Bioética y salud mental. Vertex (Buenos Aires) 2000; 11: 34-37.

12. Lolas F. Sobre constructivismo moral: necesidad de una axiografía empírica. Acta Bioethica (Santiago de Chile) 2000; 6: 219-229.

13. Mezzich JE. The dialogal basis of our profession: Psychiatry with the person. World Psychiatry 2007; 6: 129-130.

14. Lolas F. Proposiciones para una teoría de la medicina. Santiago de Chile: Editorial Universitaria; 1992.

Recibido: 24 de septiembre de 2008

Aceptado: 30 de septiembre de 2008 